Research Journal of Applied Sciences, Engineering and Technology 5(4): 1351-1357, 2013

DOI:10.19026/rjaset.5.4872

ISSN: 2040-7459; e-ISSN: 2040-7467

(C) 2013 Maxwell Scientific Publication Corp.

Submitted: July 05, 2012

Accepted: July 31, 2012

Published: February 01, 2013

\title{
Research Article \\ Surface Modification of Commercially Pure Titanium by Plasma Nitrocarburizing at Different Temperatures and Duration Process
}

\author{
${ }^{1}$ Agung Setyo Darmawan, ${ }^{2}$ Waluyo Adi Siswanto and ${ }^{3}$ Tjipto Sujitno \\ ${ }^{1}$ Jurusan Teknik Mesin, Universitas Muhammadiyah Surakarta (UMS), Pabelan, \\ Surakarta 57102, Indonesia \\ ${ }^{2}$ Department of Engineering Mechanics, Universiti Tun Hussein Onn Malaysia, 86400 Parit Raja, \\ Batu Pahat, Johor, Malaysia \\ ${ }^{3}$ National Nuclear Energy Agency (BATAN), Yogyakarta 55281, Indonesia
}

\begin{abstract}
One of potential metals to be used in biomechanical applications is the commercially pure (cp) titanium. This material requires a process to improve the mechanical properties of the surface, because it is relatively soft. The purpose of this study is to determine the effect of plasma nitro carburizing process to cp titanium surface hardness. In this study, cp titanium plasma nitro carburizing process is conducted at different temperatures, i.e., at $350^{\circ} \mathrm{C}$ for 3 , 4 , and $5 \mathrm{~h}$, and at $450^{\circ} \mathrm{C}$ for 2,3 , and $4 \mathrm{~h}$, respectively. Hardness tests are then performed on each specimen. The depth of penetration in the hardness test is also recorded; the microstructure captures are also taken using an optical microscope. The results show that the longer processing time, the higher the hardness value. In higher temperature, the hardness values correspond to the increasing temperature. In terms of the depth direction, there is a reduction in hardness value compared to the raw material.
\end{abstract}

Keywords: Biomechanics, diffusion, hardness, surface hardening, vickers

\section{INTRODUCTION}

Titanium was first discovered in England by W. Gregor in 1791 and named in 1794 by H. Klaproth (Aladjem, 1973). In Mendeleef's periodic table, titanium is one of the transition elements in group IV and period 4 . The material has low density property relative to other structural metals and alloys, but it has an excellent corrosion resistance (Tan and Zhu, 2007; Yu et al., 2005; Dong and Bell, 2000). Table 1 shows the physical properties of unalloyed titanium. Nowadays, titanium is widely used in industry and medical field (Trtica et al., 2006; Fu and Batchelor, 1998; Luo and Ge, 2009; Hamada et al., 2002).

In industry, about $80 \%$ of its usage is in the field of aerospace, besides that, the use of a pretty significant also in the field of chemical and petrochemical (Bloyce et al., 1994).

Due to its biocompatibility, titanium is used in medical applications including surgical implement and implants, such as hip balls and sockets (hip joint replacement) that can last up to 20 years (Schank, 2012). Titanium is also used in other several medical fields such as dental implant materials, bone fitting, replacement of the skull, and the retaining structure of the heart valves (Liu et al., 2004a; Liu et al., 2004b; Tian et al., 2005; Shenhar et al., 1999). Because
Table 1: Physical properties of unalloyed titanium (Liu et al., 2004a)

\begin{tabular}{ll}
\hline Property & Value \\
\hline Atomic number & 22 \\
Atomic weight $(\mathrm{g} / \mathrm{mol})$ & 47.90 \\
Crystal structure & \\
Alpha, hexagonal, closely packed & \\
$C(\AA)$ & $4.6832 \pm 0.0004$ \\
$a(\AA)$ & $2.9504 \pm 0.0004$ \\
Beta, cubic, body centered & \\
$a(\AA)$ & $3.28 \pm 0.003$ \\
Density $\left(\mathrm{g} / \mathrm{Cm}^{3}\right)$ & 4.54 \\
Coefficient of thermal expansion, $\alpha$, at & $8.4 \times 10^{-6}$ \\
$20^{\circ} \mathrm{C}\left(\mathrm{K}^{-1}\right)$ & \\
Thermal conductivity $(\mathrm{W} /(\mathrm{mK}))$ & 19.2 \\
Melting temperature $\left({ }^{\circ} \mathrm{C}\right)$ & 1668 \\
Boiling temperature $(\mathrm{estimated})\left({ }^{\circ} \mathrm{C}\right)$ & 3260 \\
Transformation temperature $\left({ }^{\circ} \mathrm{C}\right)$ & 882.5 \\
Electrical resistivity & \\
High purity $(\mu \Omega \mathrm{Cm})$ & 42 \\
Commercial purity $(\mu \Omega \mathrm{Cm})$ & 55 \\
Modulus of elasticity, $\alpha,(\mathrm{GPa})$ & 105 \\
Yield strength, $\alpha,(\mathrm{MPa})$ & 692 \\
Ultimate strength, $\alpha,(\mathrm{MPa})$ & 785 \\
\hline
\end{tabular}

titanium is a non-ferromagnetic material, the implant to the patient is very safe with magnetic resonance imaging.

Available titanium which is commonly used in the hip joint replacement is Ti-6Al-4V Titanium Alloy. When wearing is one of parameters that mostly considered, the Titanium alloy has a good wear resistance. But, there are some concerns about the

Corresponding Author: Agung Setyo Darmawan, Jurusan Teknik Mesin, Universitas Muhammadiyah Surakarta (UMS), Pabelan, Surakarta 57102, Indonesia

This work is licensed under a Creative Commons Attribution 4.0 International License (URL: http://creativecommons.org/licenses/by/4.0/). 
toxicity of $\mathrm{Al}$ and $\mathrm{V}$ wear debris in the human body that might negative side effects to the human body. For this reason, the use of cp titanium is a potential metal and safer to replace Ti-6Al-4V Titanium Alloy bearings.

However, when $\mathrm{cp}$ titanium is used as a part of which will experience friction with other parts such as that is in hip joint replacement, then the addition of the hardness value will be required (Ali et al., 2011; Darmawan et al., 2010). However when the hardness is increased by a certain treatment to the whole part, there is a possibility the material will become brittle, which is not expected. Any excessive loading applied to the material will damage it easily.

Increasing the hardness at the surface without changing the ductility properties of materials on the inside of the material will increase the toughness properties of material without changing the ductility if the inner part. This process is referred to as surface hardening.

Several surface hardening techniques can be used to increase hardness of titanium and its alloy such as: Ion implantation (Ali et al., 2011; Huang et al., 2004; Jagielski et al., 2006) plasma spraying (Liu et al., 2004b; Miklaszewski et al., 2011), laser beam (Tian et al., 2005; Grenier et al., 1997), vacuum (Kim et al., 2009), and powder immersion reaction (Shenhar et al., 1999).

Diffusion methods of surface hardening modify the chemical composition of the surface with hardening species such as nitrogen, carbon, or boron. These methods allow effective hardening of the entire surface of a part and are generally used when a large number of parts are to be surface hardened. One of the diffusion methods is Nitro carburizing.

Nitro carburizing is a thermo chemical process in which a process of diffusion of nitrogen and carbon atoms toward the surface of metallic materials at certain elevated temperatures. Heat is needed to enhance the diffusion of hardening species into the material's surface. Nitro carburizing can be applied to liquid, solid, and plasma atmospheres. Nitro carburizing widely used to increase the hardness value in the surface of steel (Krishnaraj et al., 1998; Bell et al., 2000).

Jones (2012) defined that plasma is different with traditional phase of matter such solids, liquids, and gases. Plasma is a collection of charged particles that respond strongly and collectively to electromagnetic fields, taking the form of gas-like clouds or ion beams. Since the particles in plasma are electrically charged (generally by being stripped of electrons), it is frequently described as an ionized gas.

It was Irving Langmuir who assigned the term "plasma". Langmuir and his colleague, Albert W. Hull, contributed a joint paper and used the term plasma on grid-controlled gas tubes to the National Academy of Science in 1929 (Brittain, 2010).
The plasma nitro carburizing produces faster nitrogen and carbon diffusion, more friendly with environment, more economical, and, lower gas consumption compared to other nitro carburizing techniques (Karakan et al., 2004).

In this study, the influences of plasma nitro carburizing to hardness of $\mathrm{cp}$ titanium's surface are investigated. Hardness, one of mechanical property that important to consider, is a measure of a material's resistance to localized plastic deformation (e.g., a small dent or a scratch). Hardness is an indicator of wear resistance and ductility. The instrument used to measure the hardness is Micro Vickers. Micro Vickers is referred to as micro indentation-testing method on the basis of indenter size. It is well suited for measuring the hardness of small, selected specimen regions (Callister, 2007). Hardness test is very useful for materials evaluation, quality control of manufacturing processes, and development effort.

\section{MATERIALS AND METHODS}

The material used for this work is cp titanium. The chemical composition of $\mathrm{cp}$ titanium is as follows: $\mathrm{N}$ : $0.04 \%$, C: $0.05 \%$, H: $0.003 \%$, Fe: $0.13 \%$, O: $0.11 \%$, Al: $0.49 \%$ S: 0.03 , Ti: balance. Micro structure photograph of this material can be seen in Fig. 1 the capture shows that the material consists of $100 \% \alpha$-phase and that there is no $\beta$-phase present. $\alpha$-phase has a unit cell of hexagonal close packed (hcp) and $\beta$-phase has body center cubic (bcc).

Regarding to plasma nitro carburizing processes, cp titanium material is cut with the size of $1 \times 1 \times 0.3 \mathrm{Cm}$. Specimens as many as 6 pieces created for this purpose. Three specimens used in the process of plasma nitro carburizing at $350^{\circ} \mathrm{C}$ while the other 3 are used at $450^{\circ} \mathrm{C}$. Then the material is grinded and polished using polycrystalline diamond until it is clean and shiny.

In plasma nitro carburizing process, the plasma is formed in a vacuum by means of high voltage electrical energy in which the positive ions of nitrogen, carbon and hydrogen are accelerated to strike the cathode. The work piece is maintained at a negative dc high voltage source of 250-850 volts in the presence of an electric field. The gases are separated, ionized, and accelerated toward the work piece (cathode). The kinetic energy of ion is converted into heat energy by ion bombardment. This energy not only heating the work piece but also implanting ions directly and resulting the cathode

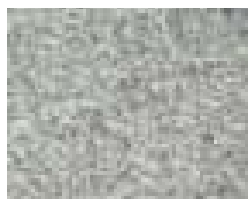

Fig. 1: Microstructure of $\mathrm{cp}$ titanium 


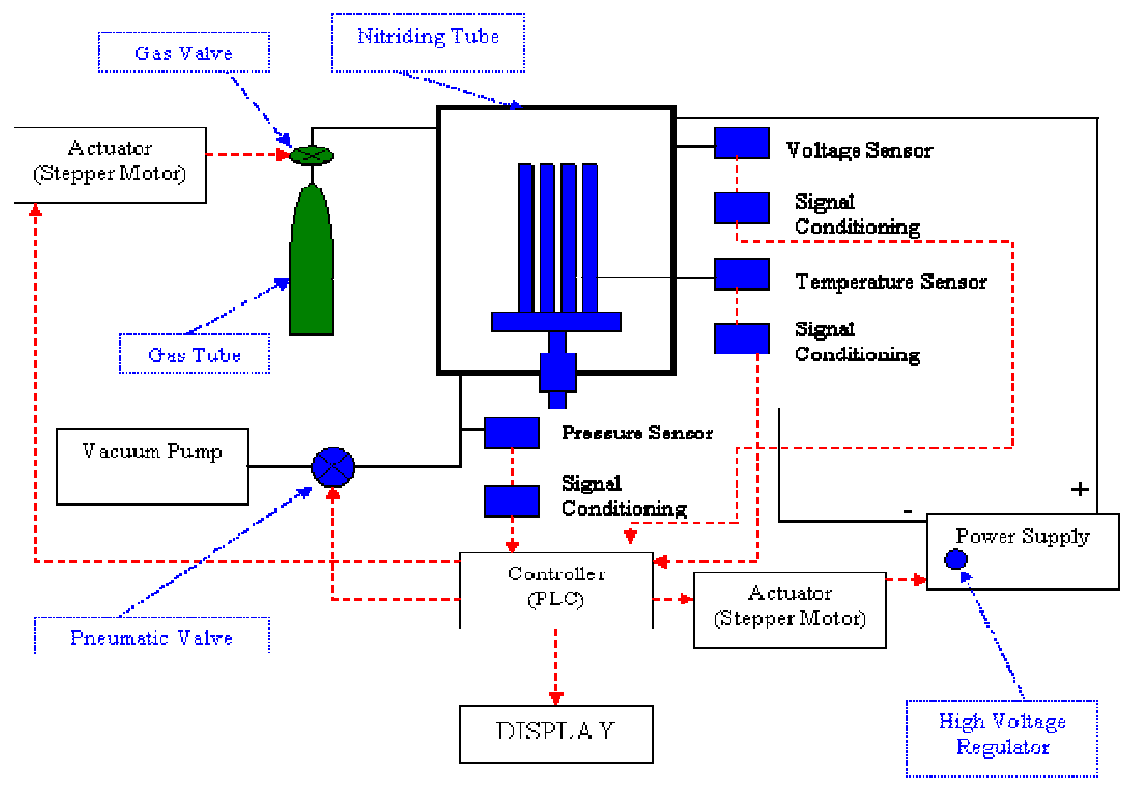

Fig. 2: Schematic diagram of devices for plasma nitro carburizing

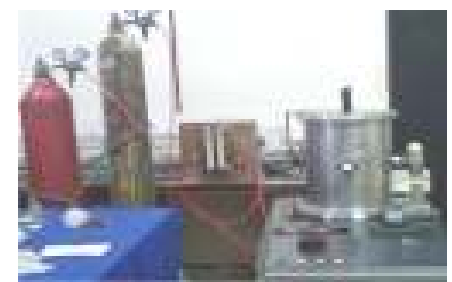

Fig. 3: Photograph of the device arrangement for plasma nitro carburizing

sputtering. The electrons are forced out from the surface of the work piece. Some of the ions implanted into the surface of the specimen, the other led to the cathode sputtering. Furthermore, absorption and diffusion of nitrogen and carbon atoms led to the formation of the compound layer. The schematic of equipment setup and photograph of the device arrangement for plasma nitro carburizing can be seen in Fig. 2 and 3, respectively.

Plasma nitro carburizing processes are carried out in 2 elevated temperature i.e., 350 and $450^{\circ} \mathrm{C}$, respectively. In the plasma nitro carburizing at $350^{\circ} \mathrm{C}, 3$ work pieces are tested in different duration processes; 3,4 , and $5 \mathrm{~h}$ respectively. In another experiment at temperature of $450^{\circ} \mathrm{C}$, the nitro carburizing process of 3 samples are hold in different duration; 2, 3, and $4 \mathrm{~h}$, respectively.

For the plasma nitro carburizing process with temperature of $350^{\circ} \mathrm{C}$, the pressure condition is maintained at 1.6 mbar. The electrical charge for the process is at 592 volt, with the current on $249 \mathrm{~mA}$. At the temperature of $450^{\circ} \mathrm{C}$, the voltage is set higher at 745 volt, with the current $357 \mathrm{~mA}$.
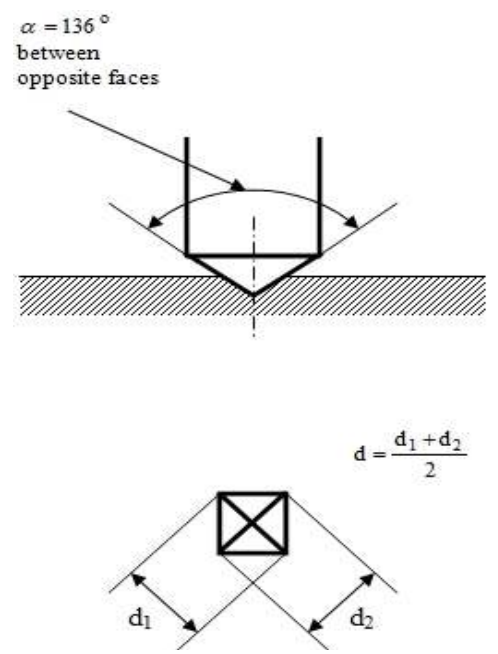

Fig. 4: Vickers hardness test

After the plasma nitro carburizing process completed, each specimen is tested of its hardness using a micro vickers hardness tester.

Prior to hardness testing, a careful surface preparation (grinding and polishing) is conducted to ensure a well-defined indentation that may be accurately measured. This hardness test follows the standard ASTM E 384. The micro-hardness measurement works with indenter force as light as $10 \mathrm{gf}$ (gram force), with indentation time in $15 \mathrm{sec}$. The indenter is a square-based pyramidal-shaped diamond with a face angle of $136^{\circ} \mathrm{C}$. This indenter and its diagonals of impression are illustrated in Fig. 4. After force removal, the impression diagonals are measured 


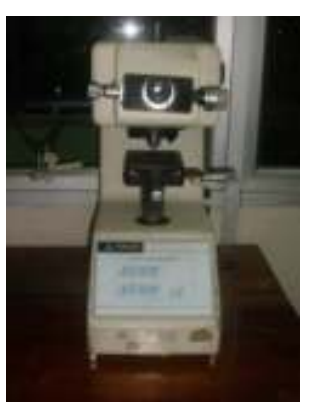

Fig. 5: Karl frank GMBH type 38505 buehler micro hardness tester

with a light microscope. It is assumed that the indentation does not undergo elastic recovery after force removal.

The Vickers hardness number can be determined by the following equation:

$$
H V=1,854 p / d^{2}
$$

where,

$\mathrm{P}$ : The applied force $(\mathrm{Kg})$

$\mathrm{d}$ : Mean diagonal of impression $(\mathrm{mm})$

Karl Frank GMBH Type 38505 micro hardness tester is used for measuring the hardness of the specimen. This micro hardness tester can be seen in Fig. 5.

\section{RESULTS AND DISCUSSION}

The results are analyzed and plotted to see the effect of plasma nitro carburizing process time and temperature process to the material hardness and to see the hardness trend in to the variation of depth direction.

Effect of process time and temperature to material hardness: Hardness testing is conducted at 3 locations on the surface of the specimen, namely the location A, $\mathrm{B}$ and $\mathrm{C}$. Figure 6 shows these locations. After hardness testing, the mean diagonal of impression is obtained and then it is used to calculate the vickers hardness. The result can be seen in Table 2 and 3 .

As an example calculation, the data obtained from plasma nitro carburizing process at temperatures of $350^{\circ} \mathrm{C}$ with a time of $3 \mathrm{~h}$ at the location $\mathrm{A}$ is calculated according to Eq. (1). Then the hardness, HV, is obtained as follows:

$$
\begin{aligned}
& H V=1,854 P / d^{2} \\
& =1,854 \times 0.01 / 0.50^{2} \\
& =74.16
\end{aligned}
$$

\begin{tabular}{|c|c|c|c|c|c|c|}
\hline $\begin{array}{l}\text { Duration } \\
\text { (h) }\end{array}$ & Location & $\mathrm{d}_{1}(\mathrm{~mm})$ & $\mathrm{d}_{2}(\mathrm{~mm})$ & $\mathrm{d}(\mathrm{mm})$ & $\mathrm{HV}$ & $\mathrm{HV}_{\text {average }}$ \\
\hline \multirow[t]{3}{*}{3} & $\mathrm{~A}$ & 0.50 & 0.50 & 0.50 & 74.16 & 74.16 \\
\hline & B & 0.50 & 0.50 & 0.50 & 74.16 & \\
\hline & $\mathrm{C}$ & 0.50 & 0.50 & 0.50 & 74.16 & \\
\hline \multirow[t]{3}{*}{4} & A & 0.45 & 0.45 & 0.45 & 91.56 & 92.25 \\
\hline & B & 0.45 & 0.45 & 0.45 & 91.56 & \\
\hline & $\mathrm{C}$ & 0.44 & 0.45 & 0.45 & 93.62 & \\
\hline \multirow[t]{3}{*}{5} & $\mathrm{~A}$ & 0.45 & 0.45 & 0.45 & 92.93 & 94.41 \\
\hline & B & 0.43 & 0.43 & 0.43 & 98.73 & \\
\hline & $\mathrm{C}$ & 0.45 & 0.45 & 0.45 & 91.56 & \\
\hline
\end{tabular}

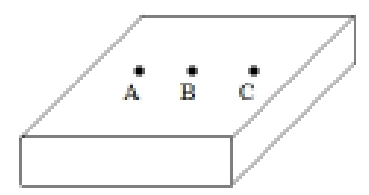

Fig. 6: Hardness testing locations

Table 3: Process plasma nitro carburizing at temperature $450^{\circ} \mathrm{C}$

\begin{tabular}{lllllll}
\hline $\begin{array}{l}\text { Duration } \\
(\mathrm{h})\end{array}$ & Location & $\mathrm{d}_{1}(\mathrm{~mm})$ & $\mathrm{d}_{2}(\mathrm{~mm})$ & $\mathrm{d}(\mathrm{mm})$ & $\mathrm{HV}$ & $\mathrm{HV}_{\text {average }}$ \\
\hline 2 & $\mathrm{~A}$ & 0.40 & 0.40 & 0.40 & 115.88 & 103.70 \\
& $\mathrm{~B}$ & 0.40 & 0.40 & 0.40 & 115.88 & \\
& $\mathrm{C}$ & 0.48 & 0.48 & 0.48 & 79.360 & \\
3 & $\mathrm{~A}$ & 0.40 & 0.40 & 0.40 & 115.88 & 121.31 \\
& $\mathrm{~B}$ & 0.38 & 0.38 & 0.38 & 126.17 & \\
4 & $\mathrm{C}$ & 0.39 & 0.39 & 0.39 & 121.89 & \\
& $\mathrm{~A}$ & 0.38 & 0.38 & 0.38 & 126.17 & 126.17 \\
& $\mathrm{~B}$ & 0.38 & 0.38 & 0.38 & 126.17 & \\
& $\mathrm{C}$ & 0.38 & 0.38 & 0.38 & 126.17 & \\
\hline
\end{tabular}

Similarly, the hardness at location B and C is obtained. The hardness at location $\mathrm{B}$ is 74.16 and the hardness at location $\mathrm{C}$ is 74.16 .

Average hardness of locations $\mathrm{A}, \mathrm{B}$, and $\mathrm{C}$ is the following:

$$
\begin{aligned}
& H V_{\text {average }}=\frac{H V_{A}+H V_{B}+H V_{C}}{3} \\
& =\frac{74.16+74.16+74.16}{3} \\
& =74.16
\end{aligned}
$$

Furthermore, the average hardness is used as the hardness property from each specimen.

The hardness values for the plasma specimens nitro carburizing processes at temperatures of $350^{\circ} \mathrm{C}$ for process duration of 3,4 , and $5 \mathrm{~h}$ are $74.16,92.25$ and 94.41 HV, respectively.

There is a significant increased in hardness value when the process duration is extended from $3 \mathrm{~h}$ to $4 \mathrm{~h}$. The hardness can be improved as high as $24.4 \%$.

The hardness improvement, however does not show a linear behavior when the process time is extended. When the process time is extended to $5 \mathrm{~h}$, the hardness value is increased only $2.3 \%$. The hardness 


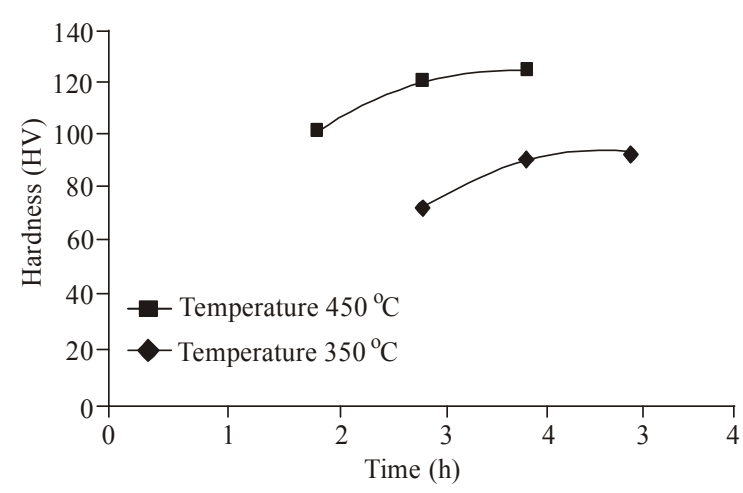

Fig. 7: The hardness values in the surface of specimen which is processed plasma nitro carburizing at temperatures 350 and $450^{\circ} \mathrm{C}$

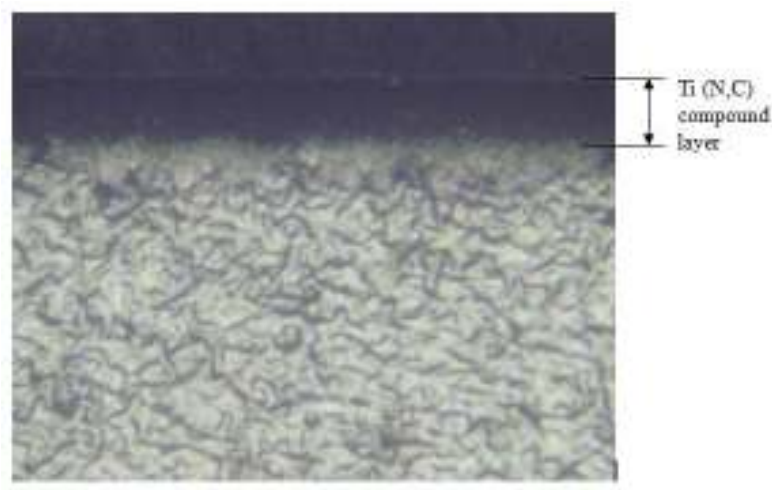

Fig. 8: Ti (N, C) compound layer which is resulted by using plasma nitro carburizing process at temperatures $350^{\circ} \mathrm{C}$ for $4 \mathrm{~h}$

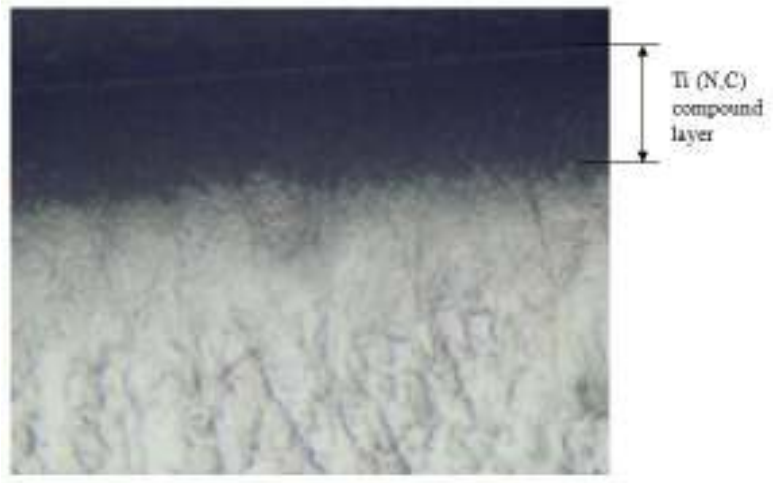

Fig. 9: Ti (N, C) compound layer which is resulted by using plasma nitro carburizing process at temperatures $450^{\circ} \mathrm{C}$ for $4 \mathrm{~h}$

improvement is not significant when it is compared with that of process time extension from 3 to $4 \mathrm{~h}$. The hardness values are illustrated in Fig. 7.
Figure 7 shows that hardness value of specimens which are resulted from the plasma nitro carburizing process at temperature of $450^{\circ} \mathrm{C}$ is higher compared with specimens that are processed at temperature of $350^{\circ} \mathrm{C}$. Specimens are processed at temperature of $450^{\circ} \mathrm{C}$ for 3 and $4 \mathrm{~h}$ show hardness values of 121.31 and HV 126.17, respectively. While, those are processed at temperature of $350^{\circ} \mathrm{C}$ have hardness values of 74.16 and $92.25 \mathrm{HV}$ for the process time 3 and $4 \mathrm{~h}$.

The results of hardness test showed that the higher the temperature, the hardness value will be higher, and the longer the test time, the higher the hardness value. This is because the diffusion of carbon and nitrogen atoms depends on the time and temperature. The higher the time and temperature, the more diffusion of carbon and nitrogen atoms and the distance is longer as well. Furthermore, the layer compound $\mathrm{Ti}(\mathrm{N}, \mathrm{C})$ which is formed also thicker (Fig. 8 and 9) so the hardness become higher.

Hardness analysis in depth direction: Hardness test results in various depth directions are shown in Fig. 10. The hardness of the specimens which is processed by using plasma nitro carburizing at temperatures of $450^{\circ} \mathrm{C}$ has a value as high as $126.17 \mathrm{HV}$ on the surface. The hardness values in the depth directions of $0.61,0.92$ and $1.5 \mathrm{~mm}$ are recorded at the level of $63.49,53.47$ and $54.16 \mathrm{HV}$, respectively.

The hardness values of the specimens after plasma nitro carburising process at temperature of $350^{\circ} \mathrm{C}$ are the following: on the surface $92.25 \mathrm{HV}$, in depth directions of $0.30,0.6$ and $1 \mathrm{~mm}$ are as high as 56.29, 54.85, and $53.47 \mathrm{HV}$, respectively.

For specimens which are processed by using plasma nitro carburizing at temperatures of $450^{\circ} \mathrm{C}$, the hardness values at depth of 0.92 and $1.5 \mathrm{~mm}$ are recorded at the level of 53.47 and $54.16 \mathrm{HV}$. After the treatment process at temperature $350^{\circ} \mathrm{C}$, hardness values at depth of 0.6 and $1 \mathrm{~mm}$ are as high as 54.85 , and $53.47 \mathrm{HV}$. Comparing with the results at higher temperature $\left(450^{\circ} \mathrm{C}\right)$, the results do not show a significant difference. The average hardness of the raw material without any treatment is $53.99 \mathrm{HV}$.

Figure 10 also shows that the surface hardness value of specimen which is processed plasma nitro carburizing at temperatures of $450^{\circ} \mathrm{C}$ for $4 \mathrm{~h}$ increased by $134 \%$. The increase was higher than the hardness value of specimen which is processed plasma nitro carburizing at temperatures of $350^{\circ} \mathrm{C}$ for $4 \mathrm{~h}$, which only increased by $71 \%$. These results show that the hardness on the surface can be significantly improved from the initial hardness level of untreated material $53.99 \mathrm{HV}$.

The plasma carburizing treatment at higher temperature does not significantly change the hardness 


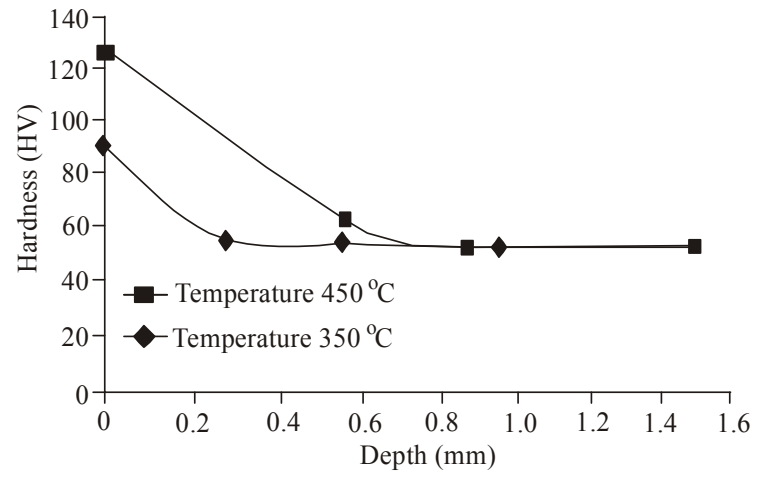

Fig.10: The hardness values in the depth direction of specimen which is processed plasma nitro carburizing at temperatures 350 and $450^{\circ} \mathrm{C}$ for $4 \mathrm{~h}$

properties of the material below the surface. The treatment at both temperatures of 350 and $450^{\circ} \mathrm{C}$ can significantly improve the hardness on the surface, while inside the material the hardness remains unchanged. This indicates that the plasma nitro carburizing has a significant effect on the surface which is favorable. In biomechanical applications it is intended that the surface treatment to increase the surface hardness but maintaining the mechanical properties of the material. Since the hardness of the material below the surface is not change the ductility of the material will not be changed.

\section{CONCLUSION}

In this research, the surface hardness of $\mathrm{cp}$ titanium is modified and improved by using plasma nit carburizing process. The effects of such processes to hardness value can be concluded as the followings:

- The hardness value of cp titanium can be increased by extending the time during the plasma nitro carburizing process. The increasing hardness rate however does not show a linear behavior as shown at temperature of 350 and $450^{\circ} \mathrm{C}$.

- The hardness value resulted from the plasma nitro carburizing process at temperature $450^{\circ} \mathrm{C}$ is higher compared with that at temperature $350^{\circ} \mathrm{C}$.

- The surface hardness value of specimen which is processed plasma nitro carburizing at temperatures of $350^{\circ} \mathrm{C}$ for $4 \mathrm{~h}$ increased by $71 \%$ while those processed at temperatures of $450^{\circ} \mathrm{C}$ for $3 \mathrm{~h}$ increased by $125 \%$. However, there is no significant increasing of hardness after extending the processing time.

- The higher the time and temperature of process, the more diffusion of carbon and nitrogen atoms and the distance is longer as well. Furthermore, the layer compound $\mathrm{Ti}(\mathrm{N}, \mathrm{C})$ which is formed also thicker so the hardness become higher.

- The plasma nitro carburizing of cp titanium can significantly increase the hardness on the surface but does not have significant effect below the surface. This shows that this treatment is suitable for improving the hardness of the surface while maintaining the original properties of the $\mathrm{cp}$ titanium.

\section{ACKNOWLEDGMENT}

The authors gratefully acknowledge financial support from Universiti Tun Hussein Onn Malaysia under Fund Scheme GIS Vot 0809. The authors also would like to thank Accelerator Application Group of BATAN-Yogyakarta Indonesia for allowing plasma nitro carburizing processes be conducted in its laboratory; Material Laboratory of Universitas Gajah Mada Indonesia for microvickers hardness test and Mechanical Engineering Laboratory of Universitas Muhammadiyah Surakarta for all specimens preparation.

\section{REFERENCES}

Aladjem, A., 1973. Anodic oxidation of titanium and its alloys. J. Mater. Sci., 8(5): 688-704.

Ali, N., H. Samekto, M.I. Ghazali and M. Ridha, 2011. Surface Modification of Pure Titanium by Nitrogen Ion Implantation at Different Beam Energy and Dose. Key Eng. Mater., 462-463: 750-755.

Bell, T., Y. Sun and A. Suhadi, 2000. Environmental and technical aspects of plasma nitrocarburizing. Vacuum, 59(1): 14-23.

Bloyce, A., P.H. Morton and T. Bell, 1994. Surface Engineering of Titanium and Titanium Alloys. ASM Handbook, 5: 2232-2233.

Brittain, J.E., 2010. Electrical engineering hall of fame: Irving Langmuir. Proc. IEEE, 98(12): 2252-2254.

Callister, W.D., 2007. Materials Science and Engineering: An Introduction 7th Edn., John Wiley and Son, Hoboken, pp: 721, ISBN: 0471736961.

Darmawan, A.S., W.A. Siswanto and H. Samekto, 2010. Effect of Femoral Head Size to Contact Stress at Pure Titanium Femoral Ball Head Outer Surface of Hip Joint Implant. Proceeding of National Conference on Advanced Manufacturing and Materials, Universiti Tun Hussein Onn Malaysia, Malaysia.

Dong, H. and T. Bell, 2000. Enhanced wear resistance of titanium surfaces by a new thermal oxidation treatment. Wear, 238(2): 131-137. 
Fu, Y. and A.W. Batchelor, 1998. Laser nitriding of pure titanium with $\mathrm{Ni}, \mathrm{Cr}$ for improved wear performance. Wear, 214(1): 83-90

Grenier, M., D. Dube, A. Adnot and M. Fiset, 1997. Microstructure and wear resistance of CP titanium laser alloyed with a mixture of reactive gases. Wear, 210(1-2): 127-135

Hamada, K., M. Kon, T. Hanawa, K. Yokoyama, Y. Miyamoto and K. Asaoka, 2002. Hydrothermal modification of titanium surface in calcium solutions. Biomaterials, 23(10): 2265-2272.

Huang, N., P. Yang, Y.X. Leng, J. Wang, H. Sun, J.Y. Chen and G.J. Wan, 2004. Surface modification of biomaterials by plasma immersion ion implantation. Surf. Coat. Technol., 186(1-2): 218-226.

Jagielski, J., A. Piatkowska, P. Aubert, L. Thome, A. Turos and A.A. Kader, 2006. Ion implantation for surface modification of biomaterials. Surf. Coat. Technol., 200(22-23): 6355-6361.

Jones, A.Z., 2012. Plasma, Retrieved from: http:// physics. about.com/od/glossary/g/ plasma. htm, (Accessed on: June 18, 2012).

Karakan, M., A. Alsaran and A. Celik, 2004. Effect of process time on structural and tribological properties of ferritic plasma nitrocarburized AISI 4140 steel. Mater. Design, 25(4): 349-353.

Kim, Y.Z., T. Konno, T. Murakami, T. Narushima, and C. Ouchi, 2009, Surface hardening treatment for titanium materials using $\mathrm{Ar}-5 \% \mathrm{CO}$ gas in combination with post heat treatment under vacuum. Mater. Trans., 50(12): 2763-2771.

Krishnaraj, N., P.B. Srinivasan, K.J.L. Iyer and S. Sundaresan, 1998. Optimization of compound layer thickness for wear resistance of Nitrocarburized H11 steel. Wear, 215(1): 123-130.

Liu, X., P.K. Chu and C. Ding, 2004a. Surface modification of titanium, titanium alloys, and related materials for biomedical applications. Mater. Sci. Eng. R Reports, 47(3-4): 49-121.
Liu, X., R.W.Y. Poon, S.C.H. Kwok, P.K. Chu and C. Ding, 2004b. Plasma surface modification of titanium for hard tissue replacements. Surf. Coat. Technol., 186: 227- 233.

Luo, Y. and G. Ge, 2009. Fretting wear behavior of nitrogen ion implanted titanium alloys in bovine serum lubrication. Tribol. Int., 42(9): 1373-1379.

Miklaszewski, A., M.U. Jurczyk, K. Jurczyk and M. Jurczyk, 2011. Plasma surface modification of titanium by TiB precipitation for biomedical applications. Surf. Coat. Technol., 206(2-3): 330-337.

Schank, C., 2012. Titanium: The Medical Metal of Choice, Retrieved from: http:// www.supraalloys.com/ medical-titanium.php, (Accessed on: June 29, 2012).

Shenhar, A., I. Gotman, E.Y. Gutmanas and P. Ducheyne, 1999. Surface modification of titanium alloy orthopaedic implants via novel powder immersion reaction assisted coating nitriding method. Mater. Sci. Eng. A, 268(1-2): 40-46.

Tan, M.J. and X.J. Zhu, 2007, Microstructure evolution of $\mathrm{CP}$ titanium during high temperature deformation. Archives Mater. Sci. Eng., 28(1): 5-11.

Tian, Y.S., C.Z. Chen, S.T. Li and Q.H. Huo, 2005. Research progress on laser surface modification of titanium alloys. Appl. Surf. Sci., 242(1-2): 177-184.

Trtica, M., B. Gakovic, D. Batani, T. Desai, P. Panjan, and B. Radak, 2006, Surface modifications of a titanium implant by a picosecond $\mathrm{Nd}$ : YAG laser operating at 1064 and $532 \mathrm{~nm}$. Appl. Surf. Sci., 253(5): 2551-2556.

Yu, H.Y., Z. B. Cai, Z.R. Zhou and M.H. Zhu, 2005. Fretting behavior of cortical bone against titanium and its alloy. Wear, 259(5): 910-918. 